\title{
God's Image and Global Cultures: Integrating Faith and Culture in the Twenty-First Century By Kenneth Nehrbass
}

Reviewed by Andrew F. Bush

God's Image and Global Cultures: Integrating Faith and Culture in the Twenty-First Century by Kenneth Nehrbass is an engaging discussion of the many issues related to culture-such as multiculturalism, diversity, pluralism, ethnocentrism and the relationship of God to culture-that confront Christians and all people in our globalized world today. Nehrbass brings a decade of service with Wycliffe Bible Translators as well as his experience as a professor at the Cook School of Intercultural Studies at Biola University to developing a theology of culture that is both theologically sound and practically helpful.

Nehrbass argues that Christians today must intentionally engage with culture, as multi-cultural connectivity is defining Western societies. In expanding this point he outlines the development of globalization since the mid-twentieth century, and how this has caused all societies to become more multi-cultural. Nehrbass states that whereas multi-national companies and missions have tried to respond to globalization by yielding to non-Western leadership, rather than withdrawal and isolation what is needed is increased multi-cultural partnership. Such partnership requires greater cross-cultural fluency.

For Christians such fluency begins with the recognition that humanity, created in the image of God, is essentially 'culturative', that is, we are makers of and participants in culture. After reviewing various theories of culture, Nehrbass argues that "the only comprehensive explanation for why being human requires being culturative is that culture is rooted in the nature of God. He creates, rules, communicates, and is social, and he made us to do the same" (72). God's plan is for culture.

Andrew F. Bush is an Associate Professor of Missiology, Chair of the Department of Global Studies and Mission, and Director of the B.A. in Missiology and Anthropology program at Eastern University. Author email: abush2@eastern.edu.
A very helpful discussion of God and the origin of ethnicity and culture undergirds Nehrbass' high view of culture. In this discussion, he explores the characteristics of culture from the creation of Adam and Eve to the fall of culture as a result of sin, and then to the role of the judgment of God at Babel and the subsequent flourishing of cultural diversity. Nehrbass helps the reader follow the various theories of God and the development of culture with succinct charts.

Nehrbass further argues that developing a theology of culture is in fact a theology for every sphere of life, as culture is inclusive of all human activity from war to art, recreation to work, religion to business. Essentially the challenge for Christians as 'World Changers' is to bring the transformation of the kingdom of God to all such spheres of life. Moving past speaking of cultural as a generality, Nehrbass then posits biblical views of various value differences between cultures such as individualist versus collectivist cultures, and task-oriented versus relationship-oriented cultures. Although the reader may not agree with his conclusions concerning the value God places on these various cultural traits, his process of analysis is helpful for those in the midst of crosscultural work.

In conclusion, Nehrbass has written a most helpful study of the relationship of God and culture which offers practical guidance for Christians as they endeavor to become informed cross-cultural workers, whether in the increasingly multicultural society in the United States or in international service. For those looking for a concise but thorough guide for responding to contemporary issues, such as the assimilation of immigrants into Western society, the effects of the exportation of Western culture, and the extent to which Christians should participate in culture change, God's Image and Global Cultures is a valuable text.

Eugene, OR: Cascade Books

2016 